Grażyna Wójcik*

ORCID: 0000-0001-9286-3775

Kielce

\title{
Wychowanie katolickie w szkołach Zgromadzenia Sióstr Służek Najświętszej Maryi Panny Niepokalanej w Mariówce w latach 1903-1954
}

Sytuacja Kościoła katolickiego w różnych okresach dziejów naszej ojczyzny była trudna. Szczególnie warunki panowały w okresie utraty przez Polskę niepodległości. W XIX wieku zaborcy prowadzili politykę zmierzającą do wynarodowienia Polaków. Największe trudności występowały w zaborze rosyjskim. Wieloletnie ograniczenia dotyczyły między innymi nauki w języku polskim i nauki religii ${ }^{1}$.

Kościół katolicki z dużą troską odnosił się do wychowania katolickiego. Mimo niesprzyjających warunków działalność dydaktyczno-wychowawczą prowadziło wiele stowarzyszeń i zgromadzenia zakonne. Sytuacja w oświacie zmieniła się po odzyskaniu niepodległości w 1918 roku. Wówczas ogłoszone zostały przepisy prawne, porządkujące różne dziedziny życia społecznego.

* Dr Grażyna Wójcik jest nauczycielką Zespołu Szkół Ponadgimnazjalnych w Drzewicy; egzaminatorem OKE w Łodzi i ekspertem na liście MEN. Adres: Zespół Szkół Ponadgimnazjalnych w Drzewicy, ul. Stanisława Staszica 5, 26-340 Drzewica; e-mail: grazynawojcik13@wp.pl.

${ }^{1}$ Edward Majcher, Działalność katechetyczna ośrodka warszawskiego w latach 1918-1939 na tle ówczesnego ruchu katechetycznego (Warszawa: Wydawnictwo Archidiecezji Warszawskiej, 1996), 17-22. 
Wśród zarządzeń z lat 1918-1954 niezwykle ważne były te, które regulowały działalność Kościoła katolickiego i prowadzonej przez niego katechizacji.

W niniejszym artykule podjęte zostało zadanie udzielenia odpowiedzi na pytanie, jaki był cel wychowania katolickiego i jak ten proces realizowano w szkołach prowadzonych przez Zgromadzenie Sióstr Służek NMP Niepokalanej w latach 1903-1954. Aby przedstawić kontekst, w którym szkoły prowadziły swoją działalność, omówiono najpierw dokumenty Stolicy Apostolskiej, Episkopatu Polski i władz państwowych, regulujące wychowanie katolickie. Następnie przedstawiono specyfikę oraz działania podejmowane w zakresie wychowania katolickiego w szkołach Zgromadzenia Sióstr Służek NMP Niepokalanej.

\section{Dokumenty Stolicy Apostolskiej, Episkopatu Polski i władz państwowych dotyczące wychowania katolickiego}

W okresie II Rzeczypospolitej nauka Kościoła katolickiego w sprawie wychowania religijnego zawarta została w dokumentach kościelnych ${ }^{2}$, takich jak: Kodeks prawa kanonicznego (1917)3, Orbem catholicum cum primum colloquimur (1923) $)^{4}$, Konkordat (1925) ${ }^{5}$, encyklika Divini Illius Magistri $(1929)^{6}$, Provido sane consilio (1935) ${ }^{7}$. Przepisy państwowe odnoszące się do tych kwestii to z kolei: Konstytucja Rzeczypospolitej Polskiej z 1921 roku$^{8}$,

2 Stanisław Adamski, Szkoła wedle nauki Kościoła i uchwał Synodu, cz. 1 (Poznań: Nakład Przewodnika Katolickiego, Drukarnia i Księgarnia św. Wojciecha, 1939), 7-8.

${ }^{3}$ Pius PP X, Codex Iuris Canonici, Pontificis Maximi iussu digestus, Benedicti XV auctoritate promulgatus (Roma, 1917).

4 Pius PP XI, „Orbem catholicum cum primum colloquimur”, Acta Apostolicae Sedis (1923): 327-329.

5 Konkordat pomiędzy Stolicą Apostolską a Rzeczypospolitą Polską, podpisany w Rzymie dnia 10 lutego 1925 r. (ratyfikowany zgodnie z ustawą z dnia 23 kwietnia 1925 r.), Dz.U. 1925, nr 47, poz. 324.

${ }^{6}$ Pius PP XI, Encyklika „Divini Illius Magistri” [O chrześcijańskim wychowaniu młodzieży], tłum. J. Korzonkiewicz (Poznań: Kancelaria Prymasa Polski, 1932); Aldona Zakrzewska, „Edukacja religijna dzieci i młodzieży szkolnej okresu międzywojennego źródłem humanizacji życia społecznego", Paedagogia Christiana 2/30 (2012): 47-53.

7 Pius PP XI, „Provido sane consilio”, Acta Apostolicae Sedis (1935): 145-154.

${ }^{8}$ Konstytucja Rzeczypospolitej Polskiej z dnia 17 marca 1921 r. podkreślała uprzywilejowany charakter religii rzymskokatolickiej. Artykuł 120 zawierał wskazanie, iż w każdym zakładzie naukowym, którego program obejmuje kształcenie młodzieży poniżej lat 18, 
ustawa o tymczasowym ustroju władz szkolnych ${ }^{9}$, ogłoszona 4 czerwca 1920 roku przez Ministerstwo Wyznań Religijnych i Oświecenia Publicznego, rozporządzenie o nauczaniu religii katolickiej ${ }^{10}$, oraz okólnik z 5 stycznia 1927 roku w sprawie nauki religii w szkołach powszechnych ${ }^{11}$, tak zwany Okólnik Bartla. Dalsze rozporządzenia dotyczyły spraw związanych z katechizacją i kwalifikacjami wymaganymi do nauczania religii ${ }^{12}$. Stanowisko prefekta szkolnego ustalone zostało w art. 13 konkordatu z 1925 roku $^{13}$. Episkopat Polski wielokrotnie zabierał głos w sprawach szkolnictwa, między innymi w sprawie ustawy o ustroju szkolnictwa z 1932 roku, przypominając, iż należy zachowywać zasadę wychowania religijno-moralnego w duchu zasad Kościoła katolickiego ${ }^{14}$.

Po wybuchu drugiej wojny światowej - 1 września 1939 roku - oraz po agresji Związku Radzieckiego na Polskę 17 września 1939 roku sytuacja dotycząca wszystkich dziedzin życia społecznego uległa gwałtownemu pogorszeniu. Wśród Polaków zrodził się ruch oporu, obejmujący nie tylko walkę zbrojną, ale także oświatę. Ogromną rolę w działalności konspiracyjnej wypełniły organizacje nauczycielskie, a także Kościół katolicki ${ }^{15}$. Po zakończeniu działań wojennych zmieniła się polityka oświatowa i relacje państwo-Kościół. Dnia 12 września 1945 roku Tymczasowy Rząd Jedności Narodowej jednostronnie wypowiedział konkordat z 1925 roku $^{16}$.

Sprawy wychowania religijnego dzieci i młodzieży były tematem posiedzenia Episkopatu Polski w dniu 24 maja 1946 roku. Kwestia ta zawarta była

utrzymywanym w całości albo częściowo przez państwo lub samorząd, nauka religii jest dla wszystkich uczniów obowiązkowa [Konstytucja Rzeczypospolitej Polskiej z dnia 17 marca 1921 r., Dz.U. 1921, nr 44, poz. 267, art. 120].

${ }_{9}$ Ustawa z dnia 4 czerwca 1920 r. o tymczasowym ustroju władz szkolnych, Dz.U. 1920, nr 50, poz. 304; Dz.Urz. MWRiOP 1920, nr 18, poz. 11.

${ }^{10}$ Rozporządzenie Ministra MWRiOP z dnia 9 grudnia 1926 r. o nauczaniu religii, Dz.U. 1927, nr 1, poz. 9.

${ }^{11}$ Okólnik MWRiOP z dnia 5 stycznia 1927 r. w sprawie nauki religii w publicznych szkołach powszechnych, Dz.Urz. MWRiOP 1927, nr 2, poz. 32.

12 Jan Szczepaniak, Troska Kościoła o nauczanie $i$ wychowanie religijne $w$ Polsce $w$ latach 1918-1927 (Kraków: Wydawnictwo WAM, 1997), 229-234; Ryszard Polak, Religia rzymskokatolicka w szkołach II Rzeczypospolitej (Lublin: Wydawnictwo Polihymnia, 2007), 154-162.

${ }^{13}$ Konkordat, art. 13.

14 Majcher, Działalność, 35-44.

15 Teresa Hejnicka-Bezwińska, Praktyka edukacyjna $w$ warunkach zmiany kulturowej (Warszawa: Wydawnictwo Naukowe PWN, 2015), 153-165.

16 Tamże, 168-174, 211-215. 
również w odezwie biskupów do wiernych w 1947 roku. Biskupi, nawiązując do encykliki Piusa XI Divini Illis Magistri (O chrześcijańskim wychowaniu młodzieży), ponownie wystąpili do rodziców z apelem, przypominając, że wychowanie młodego pokolenia jest wspólnym zadaniem: rodziny, Kościoła i państwa. W sprawie wychowania młodzieży głos zabierał także prymas Polski, arcybiskup Stefan Wyszyński. Uczynił to między innymi w liście do wiernych z 5 października $1950 \mathrm{roku}^{17}$. W kolejnych latach w wyniku nasilającej się polityki indoktrynacji w duchu socjalistycznym Kościół wielokrotnie występował w obronie wychowania religijnego młodego pokolenia.

Szczególną rolę w dziele katechizacji mieli do odegrania katecheci ${ }^{18}$ i kapłani pełniący funkcje prefektów szkolnych ${ }^{19}$. Obowiązki i zadania prefektów zawarte były w Ustawie z dnia 1 lipca 1926 roku o stosunkach służbowych nauczycieli ${ }^{20}$. Akty prawne państwowe dotyczące nauki religii i księży prefektów oraz przepisy władz kościelnych określały głównie status prawny katechezy szkolnej, a także jej nauczycieli - prefektów szkolnych. Dokumenty te wyznaczały dwa główne zadania, jakie mieli do spełnienia księża prefekci, czyli nauczanie i wychowanie oraz pracę duszpasterską. W procesie wychowania mieli oni być koordynatorami działań wychowawczych, odgrywać znaczącą rolę i dawać dobre przykłady, a zwłaszcza w praktyce wzór własnego etycznego życia ${ }^{21}$.

17 Witold Chmielewski, „Rola rodziny w wychowaniu religijnym dzieci i młodzieży w okresie powojennym”, Przegląd Historyczno-Oświatowy 1-2 (2010): 83-90.

18 „Katecheta to duchowny lub świecki świadek wiary Kościoła, uczestniczący w misji głoszenia Ewangelii, posiadający odpowiednie przygotowanie teologiczne, pedagogiczno-dydaktyczne i duchowe, nauczający na mocy misji kanonicznej” [Edward Materski, „Katecheta”, w: Encyklopedia katolicka, red. Andrzej Szostek, Bogusław Migut, Edward Gigilewicz, t. 8 (Lublin: Towarzystwo Naukowe KUL, 1989), 1014-1015].

19 „Prefekt - to kapłan wykładający naukę religii w szkołach, katecheta. Nazwa prefekt pochodzi od łac. praefectus i posiada różne znaczenia. W seminariach duchownych oznacza kapłana sprawującego nadzór nad klerykami. Oznacza także katechetę-kapłana wykładającego naukę religii w szkołach" [Władysław Kopaliński, Słownik wyrazów obcych i zwrotów obcojęzycznych (Warszawa: Wiedza Powszechna, 1989), 339].

${ }^{20}$ Zob. Obwieszczenie Ministra WRiOP z dnia 9 listopada 1932 r. w sprawie ogłoszenia jednolitego tekstu ustawy z dnia 1 lipca 1926 r. o stosunkach służbowych nauczycieli, Dz.U. 1932, nr 104, poz. 873, s. 2195.

${ }^{21}$ Agnieszka Wałęga, „Obraz edukacji religijnej w Galicji 2. połowy XIX wieku w opinii współpracowników lwowskiej Szkoły", Paedagogia Christiana 1/39 (2017): 171-198. 


\section{Specyfika wychowania katolickiego prowadzonego przez zgromadzenia zakonne}

Działalność katolickich zgromadzeń zakonnych wyrażała się na wielu płaszczyznach wychowania: religijnego, społecznego, obywatelskiego, patriotycznego, estetycznego, zdrowotnego i moralnego. Zgromadzenia wypracowywały własne pedagogie ${ }^{22}$, czyli system oddziaływań wychowawczych, związanych z charyzmatem przyjętym przez zakon.

Roman Jusiak wskazuje, iż zgromadzenia zakonne, prowadzące działalność oświatowo-wychowawczą, wypracowywały indywidualne pedagogie, których różne definicje badacz zestawia i porównuje. Według Jusiaka

pedagogia to aktywność wychowawcza podejmowana przez jednostki, organizacje, instytucje i społeczności, na podstawie ogólnie przyjętej antropologii i uznawanych wartości, a także konwencjonalnych, umownych i utrwalonych sposobów kształtowania i rozwijania osobowości wychowanków. Działalność ta obejmuje aktywność wychowawczą, nauczanie, a także w pewnym zakresie działalność opiekuńczą oraz oddziaływanie socjalizacyjne ${ }^{23}$.

Przyjęte pedagogie zakonne w swoich założeniach różniły się, miały swój niepowtarzalny, twórczy charakter, ale miały także wiele cech wspólnych, między innymi zwracały uwagę na indywidualizację procesu dydaktyczno-wychowawczego. Wniosły ogromny wkład w rozwój myśli i praktyki pedagogicznej ${ }^{24}$.

Podstawę wszystkich podejmowanych działań pedagogicznych w szkołach prowadzonych przez zgromadzenia zakonne, oprócz kształcenia intelek-

22 „Pedagogia oznacza dzieło wychowania, zespół czynności i umiejętności wychowawczych" [Stefan Kunowski, Podstawy współczesnej pedagogiki (Warszawa: Wydawnictwo Salezjańskie, 1993), 26]. „Pedagogia to zespół środków i metod wychowawczych stosowanych przez nauczycieli $[\ldots]$ praktyczną sztukę wychowania [...] program wychowawczy" [Pedagogika. Leksykon PWN, red. Bogusław Milerski, Bogusław Śliwerski (Warszawa: Wydawnictwo PWN, 2000), 144].

${ }^{23}$ Roman Jusiak, „Pedagogia franciszkańska”, w: Pedagogie katolickich zgromadzeń zakonnych. Historia i współczesność, t. 1, red. Janina Kostkiewicz (Kraków: Oficyna Wydawnicza „Impuls”, 2012), 21.

24 Janina Kostkiewicz, „Pedagogie katolickich zgromadzeń zakonnych - wprowadzenie w problematykę", w: Pedagogie katolickich zgromadzeń zakonnych. Historia i współczesność, t. 1, red. Janina Kostkiewicz (Kraków: Oficyna Wydawnicza „Impuls”, 2012), 7-19. 
tualnego, stanowiło wychowanie religijne. Celem było nauczanie powinności chrześcijańskich, wdrożenie do życia w pobożności i rozbudzenie gorliwości religijnej poprzez katechizację, wypełnianie praktyk religijnych, naukę moralności i obyczajów ${ }^{25}$.

\section{Działania w zakresie wychowania katolickiego podejmowane w szkołach Zgromadzenia Sióstr Służek NMP Niepokalanej w Mariówce w latach 1903-1954}

Znaczną rolę w procesie dydaktyczno-wychowawczym młodego pokolenia Polaków odegrało Zgromadzenie Sióstr Służek NMP Niepokalanej ${ }^{26}$. Jego założycielem był o. Honorat Koźmiński ${ }^{27}$, a siedzibą od 1903 roku Mariówka ${ }^{28}$.

Zgromadzenie Sióstr Służek NMP Niepokalanej w Mariówce w latach 1903-1954 prowadziło następujące szkoły: Szkołę Rzemiosł (1903-1910), Szkołę Gospodarczo-Rzemieślniczą (1910-1938), Prywatną Żeńską Szkołę Przysposobienia Krawiecko-Bieliźniarskiego (1938-1943), Prywatną Żeńską Szkołę Przysposobienia w Gospodarstwie Rodzinnym (1938-1940), Prywatną Szkołę Ochroniarską (1914-1918), Prywatne Seminarium Ochroniarskie (1918-1922), Prywatne Żeńskie Seminarium Nauczycielskie (1921-

${ }^{25}$ Anna Szylar, „Ideały wychowawcze w klasztornych szkołach żeńskich w okresie potrydenckim do początków XIX wieku”, Paedagogia Christiana 2 (2012): 11-14.

${ }^{26}$ Zgromadzenie Sióstr Służek NMP Niepokalanej powstało 7 października w $1878 \mathrm{r}$. podczas Święta Matki Boskiej Różańcowej. Maria Wójcik, Zgromadzenie Sióstr Stużek NMP Niepokalanej, t. 1: Powstanie, rozwój i działalność w latach 1878-1918 (Poznań: Pallottinum, 1978), 65 .

${ }^{27}$ Honorat Koźmiński (1829-1916) urodził się w Białej Podlaskiej. Na chrzcie otrzymał imiona: Florentyn Wacław Jan Stefan. Uczęszczał do szkoły elementarnej w Białej Podlaskiej, do gimnazjum w Płocku, Szkoły Sztuk Pięknych w Warszawie. Po wstąpieniu do zakonu kapucynów przyjął imię zakonne Honorat. Kierował kołami żywego różańca, zakładał zakony [Maria Mazurek, „Koźmiński Florentyn Wacław”, w: Hagiografia polska. Słownik bio-bibliograficzny, red. Romuald Gustaw, t. 1 (Poznań: Księgarnia św. Wojciecha, 1971), 864; Maria H. Mazurek, Powstanie i rozwój ukrytych Zgromadzeń bł. Honorata Koźmińskiego (Sandomierz: Wydawnictwo Diecezjalne, 2009), 55-57].

${ }^{28}$ Archiwum Główne Sióstr Służek NMP Niepokalanej (dalej: AGSł), D.I-1, Towarzystwo „Samopomoc” 1922-1933 (przychodzące), Akt hipoteczny nr 238 z 1923 r. - dobra ziemskie „Mariówka”, k. nlb.; Maria Wójcik, Stulecie działalności Zgromadzenia Sióstr Stużek NMP Niepokalanej w Mariówce (1903-2003) (Mariówka: Wydawnictwo Diecezjalne, 2004), 7; Wójcik, Zgromadzenie, t. 1, 180. 
-1936), Prywatne Żeńskie Gimnazjum Ogólnokształcące im. Królowej Jadwigi (1933-1939), Prywatne Żeńskie Liceum Ogólnokształcące im. Królowej Jadwigi (1937-1939). Po drugiej wojnie światowej funkcjonowały: Prywatna Szkoła Krawiecko-Bieliźniarska (1944-1946), Prywatne Żeńskie Gimnazjum Krawiecko-Bieliźniarskie (1946-1948), Prywatne Liceum Przemysłu Odzieżowego (1948-1952), Państwowe Gimnazjum Gospodarcze (1948-1950), Państwowe Liceum Przemysłu Gastronomicznego (1948-1950), Prywatne Koedukacyjne Gimnazjum Ogólnokształcące im. Królowej Jadwigi (1945-1950), Prywatne Koedukacyjne Liceum Ogólnokształcące im. Królowej Jadwigi (1947-1950), Prywatna Koedukacyjna Szkoła Ogólnokształcąca stopnia licealnego im. Królowej Jadwigi (1950-1954) ${ }^{29}$.

W polskiej rzeczywistości powojennej spory o kształt ideowy, tak zwana walka o „rząd dusz”, powodowały wrogie nastawienie władz oświatowych do istniejących szkół w Mariówce, ponieważ placówki te w wychowaniu młodzieży opierały się na wartościach chrześcijańskich, które nie były wówczas preferowane przez socjalistyczny system władzy. $Z$ tych powodów dokonano również likwidacji szkół zawodowych i ogólnokształcących. $\mathrm{Z}$ dniem 7 czerwca 1954 roku zamknięto działalność dydaktyczno-oświatową Zgromadzenia Sióstr Służek NMP Niepokalanej, likwidując Prywatną Koedukacyjną Szkołę Ogólnokształcącą ${ }^{30}$, a majątek szkoły i internatu przekazano nowo utworzonej Państwowej Szkole Ogólnokształcącej stopnia licealnego w Smogorzowie ${ }^{31}$.

Specyfika wychowania katolickiego w szkołach Zgromadzenia Sióstr Służek NMP Niepokalanej w Mariówce w latach 1903-1954 polegała na stosowaniu różnorodnych metod i form pracy, a także na indywidualizacji procesu dydaktyczno-wychowawczego w celu wychowania uczennic w duchu moralności chrześcijańskiej. Wymagania stawiane uczennicom zawarte były w dokumentach szkolnych ${ }^{32}$.

${ }^{29}$ Wójcik, Zgromadzenie, t. 1, 248-257; Maria Wójcik, Zgromadzenie Sióstr Stużek NMP Niepokalanej, t. 2: Rozwój i działalność w latach 1919-1978 (Sandomierz: Wydawnictwo Diecezjalne, 2012), 221-249.

30 AGSł, D.II-19, Prywatne Koedukacyjne Gimnazjum Ogólnokształcące 1945-1957, Pismo z dnia 8 czerwca 1954 r. Zgromadzenia do Ministerstwa Oświaty w Warszawie, k. nlb.

31 Tamże, Pismo z dnia 16 czerwca 1954 r. Wydziału Oświaty PWRN w Kielcach, k. nlb.; Wójcik, Zgromadzenie, t. 2, 248-249; Maria Wójcik, Prywatne Gimnazjum i Liceum Ogólnokształcace im. Błogosławionej Jadwigi w Mariówce (Sandomierz: Wydawnictwo Diecezjalne, 1995), 27-29.

32 AGSł, D.I-1, Towarzystwo „Samopomoc” 1934-1947 (odchodzące), Regulamin Bursy z 1934 r., k. nlb.; D.II-21, Szkoła Rzemiosł 1910-1924, Statut Szkoły z 1923 r. 
We wszystkich szkołach prowadzonych w Mariówce obowiązywał jeden wspólny model wychowania, który realizowany był dzięki wszechstronnej działalności dyrekcji, grona pedagogicznego, organizacji szkolnych, a także uczennic. Działania te zmierzały do ukształtowania u uczniów dojrzałej osobowości. Model ten nie był jednak stały, ulegał udoskonalaniu. Dyrekcja szkoły, nauczyciele i wychowawcy kierowali się troską o coraz lepsze oddziaływanie wychowawcze oraz zgodne z ogólnymi tendencjami wychowania.

Ujednolicony system szkolnictwa i troska państwa o wychowanie młodego pokolenia po odzyskaniu przez Polskę niepodległości w 1918 roku stwarzały duże możliwości dla rozwoju pracy pedagogicznej.

Na początku XX wieku w pedagogice pojawił się ruch reformatorski, określany nowym wychowaniem czy pedagogiką reform. Główne założenia tego kierunku koncentrowały się wokół krytyki wychowania tradycyjnego. Postulowano wychowanie spontaniczne, oparte na działaniu, samodzielnej aktywności ucznia. Henryk Rowid, polski pedagog, autor polskiego systemu szkoły twórczej, traktował wychowanie jako ważną funkcję społeczno-kulturalną, polegającą na świadomym i planowym oddziaływaniu otoczenia na młode pokolenie, a także na wyzwalaniu motywacji i sił twórczych do działania ${ }^{33}$.

W Prywatnym Żeńskim Seminarium Nauczycielskim w Mariówce przyjęto do realizacji program nowej szkoły, który zakładał, że obok dobrego wychowania uczennic do pracy w zawodzie nauczycielskim należy położyć szczególny nacisk na ich wszechstronny rozwój: intelektualny, fizyczny i moralny, oparty na zasadach katolickich. Przygotować przyszłe nauczycielki o orientacji katolickiej, uspołecznionej i twórczej, odpowiedzialne i świadome obywatelki, patriotki, dbające o rozwój odrodzonej Polski ${ }^{34}$.

Kształtowanie wychowania religijnego odbywało się poprzez wskazywanie prawd wiary katolickiej, zachęcanie do sumiennego wypełniania praktyk religijnych, które wpływały na głębsze przeżycia religijne młodzieży. W celu realizacji tych postanowień przyjęto zasady wychowania i nauczania, takie jak: zasada indywidualizacji, zasada wszechstronności i jedności, zasada ewolucji postępu, zasada środowiskowa, zasada aktywności, zasada wewnętrznej prawdziwości ${ }^{35}$.

${ }^{33}$ Henryk Rowid, Podstawy i zasady wychowania (Warszawa: Wydawnictwo Oświatowe „Wspólna Sprawa”, 1957), 89.

${ }^{34}$ Maria Wójcik, „Prywatne Seminarium Nauczycielskie Żeńskie w Mariówce Opoczyńskiej w latach 1921-1936", Studia Sandomierskie 6 (1990): 540.

35 Powyższe zasady wychowania i nauczania potraktowane łącznie po raz pierwszy wy- 
Ponadto podczas godzin wychowawczych omawiano zagadnienia dotyczące sposobów kształtowania charakterów (jak wyrabia się szlachetny charakter), a także jak unikać złych wpływów (czym psuje się charakter) czy jak zwalczać nieżyczliwość. Uczennicom wyjaśniano, jak można „popsuć” swój charakter przez obcowanie z ludźmi nieszlachetnymi, którzy są obłudni, złośliwi, nieszczerzy itp. Zalecano, aby unikać kontaktu z osobami, które mają zły wpływ na charakter innych, ostrożnie zawierać przyjaźnie i zdecydowanie zrywać ze złym wpływem. Wskazywano, iż nieżyczliwość wypływa najczęściej z pychy, niechęci oraz zazdrości i ujawnia się w różnej postaci: słowach, zachowaniu, obojętności. W postawach uczennic apelowano o heroizm, wyrażający się w ofiarnych uczynkach, podejmowanych przez ludzi posiadających wiele miłości do Boga i bliźniego. Wskazywano, iż szlachetny charakter można wypracować przez panowanie nad popędami, umiejętność dostrzeżenia $\mathrm{w}$ ludziach cech dodatnich, pomaganie ludziom $\mathrm{w}$ potrzebie, nawet wtedy, gdy to wymaga wiele trudu i czasu, umiejętność wybaczania, opanowywania się w gniewie, pracę na rzecz dobra wspólnego. Podczas pogadanek omawiano również cechy dobrej córki, czyli takiej, która jest posłuszna, szanuje swoich rodziców, nigdy nie mówi o nich źle, jest pomocna, nie martwi złym postępowaniem lub brakiem szczerości. W czasie lekcji wychowawczych prowadzona dyskusja polegała na tym, aby podać jak najwięcej przykładów z życia, ukazujących przejawy omawianej cechy charakteru. W dyskusji stawiano pytania, szukano odpowiedzi, jakie cechy są najwłaściwsze dla szlachetnego charakteru. Wskazywano na takie jak: pracowitość, pobożność, uczynność, roztropność, cierpliwość, współczucie, uczciwość, skromność, poświęcenie. Tematyka godzin wychowawczych była obszerna i obejmowała wszystkie dziedziny życia w domu, w szkole, w internacie, w środowisku koleżanek i kolegów oraz ludzi starszych. Podczas dyskusji na zebraniach wychowawczych zalecano uczennicom ciche przeprowadzanie rachunku sumienia i podejmowanie dobrych postanowień w celu ćwiczenia w wyzbywaniu się wad oraz nabywaniu zalet, spisywanie notatek i sprawdzanie swych postępów. Do tego służyły specjalne karty, opracowane i wydane uczennicom przez ks. Juliana Młynarczyka ${ }^{36}$.

odrębnił Henryk Rowid. W tej klasyfikacji zasad nawiązywał do propozycji innych teoretyków wychowania, działających u schyłku XIX i na początku XX w. [Rowid, Podstawy, 89-318].

${ }^{36}$ Karty te drukowane były w drukarni Szkoły Gospodarczo-Rzemieślniczej od $1922 \mathrm{r}$. [Maria Wójcik, „Działalność wydawnicza drukarni w Mariówce Opoczyńskiej Zgromadzenia Sióstr Służek NMP Niepokalanej w latach 1921-1930”, w: W kręgu dziejów Kościoła i rodziny franciszkańskiej, red. Roland Prejs (Warszawa: Bracia Mniejsi Kapucyni, 1999), 343-352]. 
W swych działaniach szkoła przyjęła prewencyjny system wychowania, który polegał na tym, aby w staraniach wychowawczych nie pozostawiać ucznia bez nadzoru, nie dopuszczać do wykroczeń. Uznano, że odpowiednim sposobem będzie obdarzenie uczennic zaufaniem, przeprowadzenie poufnej rozmowy, wskazanie właściwych zachowań. W życiu szkolnym wykluczano szpiegostwo i donosicielstwo jako postępowanie deprawujące charakter. Sprawami wychowania zajmowali się wszyscy nauczyciele i wychowawcy, jednak główna odpowiedzialność spoczywała na wychowawczyni każdej klasy, ks. Julianie Młynarczyku (uczącemu religii) i wychowawczyniach $\mathrm{w}$ internacie. Pomagały również inne nauczycielki poprzez nauczanie zasad dobrego wychowania, towarzyszenie uczennicom podczas rekolekcji, w czasie posiłków przy stole, pobytu w internacie. Wszelkie kwestie odnoszące się do wychowania i spraw szkolnych omawiano co tydzień na sesjach pedagogicznych, które były obowiązkowe dla całego grona pedagogicznego. Nauczycieli obowiązywało wystawianie uczennicom cotygodniowej oceny z postępów pilności, obyczajów i porządku.

W tradycji polskiego szkolnictwa na rolę religii w życiu społecznym zwrócili już uwagę twórcy ustaw Komisji Edukacji Narodowej. W rozdziale XI: „Nabożeństwo i odprawiający posługi duchowne”, zawarte jest wskazanie o konieczności nauczania religii: „religia i prawdziwa pobożność, będąc zasadą życia chrześcijańskiego, a poświęceniem wszystkich cnót, jest tym samym najistotniejszą częścią edukacji [...] powinność uczenia religii, pobożności, wszystkim w zgromadzeniach i szkołach Przełożonym i wszystkim nauczycielom i dozorcom wspólna"37.

Konieczność wychowania religijnego wynikała z katolickiego charakteru szkół prowadzonych w Mariówce, które realizowały treści wychowania religijnego zgodne $\mathrm{z}$ celami zapisanymi w Konstytucjach Zgromadzenia ${ }^{38}$ oraz nauką Kościoła, zawartą w encyklice Piusa XI Divini Illis Magistri (1929). Dokument ten wskazuje, iż wychowanie jest dziełem społecznym, a nie jednostki i dlatego zadanie wychowania dzieci i młodzieży należy do rodziny i państwa, natomiast w porządku nadprzyrodzonym do Kościoła. Sztuka wychowania polega na ukształtowaniu człowieka, jakim być powinien, jak ma żyć, jak postępować, aby osiągnąć wzniosły cel, do którego został stworzony - wieczną szczęśliwość. Celem chrześcijańskiego wychowania jest zapewnienie wychowankom najwyższego dobra - Boga i ziem-

37 Ustawy Komisji Edukacji Narodowej dla stanu akademickiego i na szkoty w krajach Rzeczypospolitej przepisane w Warszawie, rok 1783 (Lwów: Księgarnia Naukowa, 1930), 71.

38 AGSŁ, A.II., Konstytucje Zgromadzenia 1919-1988, k. nlb. 
skiego dobrobytu, dlatego należy współdziałać z łaską Bożą w wychowaniu prawdziwego i doskonałego chrześcijanina, ukształtowanego na wzór Chrystusa $^{39}$. W tym celu, zgodnie z postanowieniami konkordatu, zawartego przez Stolicę Apostolską z Rzeczypospolitą Polską w 1925 roku oraz z Konstytucją RP z 17 marca 1921 roku $^{40}$ we wszystkich szkołach państwowych, prywatnych i publicznych została wprowadzona nauka religii, a młodzież zobowiązana została do uczęszczania na te lekcje.

Szkoły w Mariówce były wyznaniowe. Przyjmowano do nich tylko kandydatki wyznania rzymskokatolickiego, co musiało być udokumentowane tak zwanym świadectwem moralności wydanym przez proboszcza parafii, z której pochodziły. Uznano, iż wychowanie chrześcijańskie wraz z wykształceniem ogólnym i zawodowym miało stworzyć mocny fundament do zbudowania silnego, prawego charakteru każdej uczennicy. Szczególną rolę do spełnienia w procesie wychowania mieli prefekci szkolni. Specyfikę wychowania religijnego kształtowali nauczyciele pod kierunkiem ks. Młynarczyka, który główne prawdy religijne przekazywał w sposób jasny, prosty i przekonujący i inspirował uczennice do codziennego wypełniania praktyk religijnych.

Uczennice codziennie rano obowiązywał pacierz, a także poranne rozmyślania i modlitwy, w południe Anioł Pański, wieczorem rachunek sumienia, pacierz i pieśni religijne, wspólne modlitwy przed lekcjami i po lekcjach, przy stole, przed posiłkami i po nich. W niedziele i święta obowiązywał wszystkich udział we mszy św. w kościele parafialnym w Smogorzowie lub w miejscowej kaplicy. Uroczyście obchodzono nowennę do św. Stanisława Kostki, w czasie której uczennice uczestniczyły w 3-dniowych rekolekcjach i sakramencie spowiedzi i komunii św. Drugie rekolekcje odbywały się w okresie Wielkiego Postu, w atmosferze skupienia, powagi oraz głębokiej refleksji. Podczas rozpoczęcia i zakończenia roku szkolnego społeczność szkolna uczestniczyła we mszy św. W celu ułatwienia uczennicom zrozumienia treści Ewangelii ks. Młynarczyk napisał dla nich zbiór krótkich rozmyślań pt. Ksztatcenie serca na podstawach etyki Chrystusowej ${ }^{41}$, a także modlitewnik Bóg miłością ${ }^{42}$. Uważał on, iż książka religijna odgrywa bardzo ważną rolę w wychowaniu religijnym, jest ,pokarmem dla umysłu”, wskazuje właściwe

39 Pius PP XI, Encyklika.

${ }^{40}$ Konstytucja.

${ }^{41}$ Julian Młynarczyk, Kształcenie serca na podstawach etyki Chrystusowej (Mariówka: Wydawnictwo Szkoły Rzemiosł, 1925).

42 Julian Młynarczyk, Bóg miłościa (Mariówka: Wydawnictwo Szkoły Rzemiosł, 1929). 
religijne postawy, uczy człowieka, jak stawać się lepszym i pobożniejszym ${ }^{43}$ i dlatego w szkole zorganizowano specjalną bibliotekę, której księgozbiór stanowiły książki o tematyce religijnej ${ }^{44}$.

Ksiądz Julian Młynarczyk szczególną wagę przywiązywał do kultu maryjnego. Zachęcał dziewczęta do uczestnictwa w nabożeństwach majowych oraz różańcowych w październiku. Dziewczęta gromadziły się w kościele, aby Maryi powierzyć swe troski, zapomnieć o codziennych kłopotach, umocnić swą ufność i wiarę ${ }^{45}$. Tradycją szkoły były także coroczne wyjazdy maturzystek do Częstochowy, aby podziękować Matce Bożej za opiekę i prosić o łaski na dalsze życie ${ }^{46}$.

W szkołach w Mariówce ważną rolę odgrywała działalność pozadydaktyczna, a w jej ramach działalność organizacji uczniowskich, które aktywizowały uczniów do różnych form pracy, samokształcenia oraz samodoskonalenia charakterów i zasad postępowania. Najbardziej rozpowszechnione to: samorządność uczniowska, harcerstwo, sodalicja, spółdzielczośćc ${ }^{47}$.

Największą organizacją w szkołach w Mariówce był samorząd szkolny zwany Kołem Samokształcenia „Jedność”, który powstał w 1921 roku w celu kształcenia charakteru i samodzielności: ,pracy nad wyrobieniem charakteru i rozwijaniem indywidualnych zdolności”"48 uczennic. Była to organizacja samorządowa, zrzeszająca wszystkie uczennice ${ }^{49}$. Opiekunkami Koła były: s. Bolesława Jarząbek, a następnie s. Scholastyka Berchmansa Sokó ${ }^{50}$.

W szkołach w Mariówce działały także: Grupa Literacka, Grupa Towarzysko-Sportowa, Koło Geograficzno-Przyrodnicze, drużyna harcerska, Przysposobienie Wojskowe Kobiet, Polski Czerwony Krzyż, Sodalicja Mariańska, Bractwo Straży Honorowej oraz sklepik uczniowski, chór i orkiestra ${ }^{51}$.

43 Julian Młynarczyk, Nasz internat (Mariówka: Wydawnictwo Szkoły Rzemiosł, 1943), 10.

44 AGSł, D.II-7, Kronika Sodalicji Mariańskiej w Mariówce [b.r.], k. nlb.

45 Redakcja, „Kronika”, Brzask 19 (1928): 20.

46 AGSł, D.II-6, Kronika Koła Samokształcenia „Jedność” [1921-1936] w Mariówce [b.r.] (dalej: Kronika Koła Samokształcenia „Jedność” 1921-1936), 10.

47 Jerzy Doroszewski, „Życie organizacyjne młodzieży w seminariach nauczycielskich w latach 1918-1937”, Przegląd Historyczno-Oświatowy 1-2 (2002): 71-83.

${ }^{48}$ AGSł, D.II-6, Kronika Koła Samokształcenia „Jedność” [1921-1936], Statut Koła Samokształcenia „Jedność” [b.r.], k. nlb.

49 Irena Kawińska, „Koło Samokształcenia Jedność”, Brzask 18 (1931): 11-12.

50 AGSł, D.II-6, Kronika Koła Samokształcenia „Jedność” [1921-1936]: 1.

51 Janina Chiberska, „Grupa Literacka”, Brzask 18 (1934), 18. 
Cenną inicjatywą było redagowanie pisma szkolnego Niespodzian$\mathrm{ka}$. Pierwszy jego numer wydano 15 listopada $1920 \mathrm{roku}^{52}$. W skład redakcji wchodziły członkinie Grupy Literackiej, założonej w roku szkolnym 1921/1922, prowadzonej pod kierunkiem nauczycielki - Janiny Marii Łabęckiej. W roku szkolnym 1922/1923 przewodniczącym tej grupy został ks. Julian Młynarczyk. Z jego inicjatywy zmieniono nazwę pisma z Niespodzianka na Brzask. Pierwszy numer Brzasku ukazał się w marcu 1923 roku, ostatni w maju 1939 roku, a nadzwyczajny w listopadzie 1929 roku $^{53}$.

Członkinie Grupy Literackiej propagowały twórczość wybitnych polskich pisarzy oraz czytelnictwo ${ }^{54}$. Cenną inicjatywą było zredagowanie w 1922 roku przez jedną z uczennic tekstu, który stał się hymnem szkolnym. Jego fragment brzmiał następująco:

\section{Naszym hasłem „Bóg-Ojczyzna” \\ Przy nim wiernie będziem trwać! \\ I przy haśle Bóg-Ojczyzna, \\ Póki życia będziem stać! $[\ldots]^{55}$}

Ksiądz Julian Młynarczyk był inicjatorem wielu różnorodnych działań, między innymi propagował czytelnictwo, wpływał na właściwy dobór czytanych książek. Czynił to podczas spotkań Grupy Literackiej ${ }^{56}$, starając się wytworzyć niepowtarzalną atmosferę, sprzyjającą rozwojowi uczennic. Świadczy o tym wypowiedź uczennicy: „Dzięki niemu i całemu gronu nauczycielskiemu kształci się w Mariówce wiele młodych, dobrych charakterów" 57.

Papież Pius XI w encyklice Divini Illius Magistri (1929) udzielił najwyższej pochwały istniejącym organizacjom, które podjęły trud pracy wychowania człowieka. Kościół zachęcał, aby księża - proboszczowie i prefekci tworzyli na terenie szkół organizacje religijne ${ }^{58}$. W szkołach w Mariówce ist-

52 AGSł, D.II-1, Niespodzianka z lat 1920-1923, pismo redagowane przez uczennice Prywatnego Seminarium Ochroniarskiego w Mariówce (dalej: Niespodzianka z lat 1920-1923), Niespodzianka 1 (1920).

53 D.II-12, Brzask z lat 1926-1939, pismo redagowane przez uczennice szkół Zgromadzenia Sióstr Służek NMP Niepokalanej w Mariówce, Brzask 9 (1929): 1.

${ }^{54}$ Kazimiera Czechówna, Zofia Jakubowska, „Grupa Literacka”, Brzask 34 (1936): 8-9.

55 AGSŁ, D.II-1, Niespodzianka (1920-1923), Redakcja, „Nasz hymn”, Niespodzianka (1922): 6 .

56 Czechówna, Jakubowska, „Grupa”, 9.

57 Krystyna Musielewicz, „Nowy gmach”, Brzask 42 (1937): 6.

${ }^{58}$ Pius PP XI, Encyklika, 61. 
niały organizacje o takim charakterze, były to: Sodalicja Mariańska i Bractwo Straży Honorowej Najświętszego Serca Pana Jezusa. Sodalicja Mariańska powołana została w 1928 roku. Jej moderatorem był ks. Julian Młynarczyk, a opiekunką s. Bolesława Jarząbkówna. Organizacja działała według założeń Statutu z 1928 roku. Jej celem było dążenie do wyrobienia światłych i dzielnych niewiast katolickich, świadomych wyznawanych zasad i konsekwentnych w swoim postępowaniu. W ramach Sodalicji Mariańskiej w Mariówce działały dwie sekcje: katechetyczna, której celem było przygotowanie do pracy katechetycznej przyszłych nauczycielek i pogłębianie ich wiadomości religijnych, oraz sekcja charytatywna, która troszczyła się o biedne dzieci z pobliskiej szkoły powszechnej, dostarczała im bieliznę, ubrania, książki, zabawki i przybory szkolne. Opiekowała się najbiedniejszymi mieszkańcami parafii. Sekcja ta udzielała też pomocy misjom katolickim. Sodalistki urządzały nabożeństwa maryjne oraz akademie ku czci Matki Bożej i patronki organizacji, św. Teresy od Dzieciątka Jezus. Naśladowały cnoty Maryi, podejmowały takie praktyki religijne jak: rozmyślanie, rachunek sumienia, rekolekcje, udział we mszach św., czytanie czasopism religijnych: Cześć Maryi, Przewodnik Katolicki, Rycerz Niepokalanej, Młodzież Polskiego Czerwonego Krzyża, Siewca Prawdy ${ }^{59}$. Przynależność do Sodalicji Mariańskiej wpływała na podnoszenie wiedzy religijnej, wypracowywanie pobożności, pielęgnowanie cnót Maryi. Dziewczęta uczyły się dobroci, życzliwości, przyjaźni, zaufania, wzajemnego szacunku. Rozbudzały w sobie zrozumienie, entuzjazm i zaangażowanie do pracy społecznej, kształtowały religijną dojrzałość jednostkową i społeczną.

Drugą organizacją o charakterze religijnym, działającą w szkołach w Mariówce, od 1934 roku było Bractwo Straży Honorowej Najświętszego Serca Pana Jezusa. Opiekunem tej organizacji był ks. Julian Młynarczyk. Należeli do niej: uczennice, siostry, a także ludzie świeccy. Celem tej organizacji było wynagrodzenie Najświętszemu Sercu Jezusa zniewag, jakich doznaje od ludzi. Każdy członek Bractwa wybierał sobie jedną godzinę w ciągu dnia, która nazywana była Godziną Świętą, w czasie której starał się czuwać przy sercu Bożym, głównie przed ołtarzem w kaplicy Zgromadzenia. Świętem dla Bractwa była uroczystość Najświętszego Serca Pana Jezusa. Organizacja ta służyła pogłębianiu wiary, miłości i ufności oraz osobistego kontaktu młodzieży szkolnej z Bogiem.

59 AGSł, D.II-31, Organizacje, koła zainteresowań w szkołach w Mariówce [b.r.], Notatki, k. nlb.; Natalia Zarembianka, „W służbie Marji. Przysięga”, Brzask 34 (1936): 4-5; Irena Langerówna, „Sodalicja”, Brzask 34 (1931): 14-15. 
Wśród uczennic i nauczycieli panowało zrozumienie, szacunek, koleżeńskość, serdeczna przyjaźń i empatia. Dowodem tego są listy uczennic do dyrektorki seminarium s. Wandy Józefy Sieradzkiej, w których wyrażały one szacunek, uznanie i wdzięczność za okazaną troskę i matczyną miłośćco.

Ksiądz Julian Młynarczyk ogromną wagę przywiązywał do wypracowania dojrzałej postawy religijnej, zgodnej z nauką Ewangelii ${ }^{61}$. Działalność księdza wychowanki wspominały na łamach pisma Brzask:

Jak nurkowie uzbrojeni w odpowiednie aparaty spuszczają się na dno morza, by szukać tam pereł, tak my spuszczamy się w głąb naszego serca i szukamy tam skarbu [...]. Perła jest czymś cudnym, ale leży na dnie morza przez wieki [...]. Taką perłą bezcenną, takim skarbem, nad który na ziemi nic droższego i piękniejszego nie ma, jest nasza, w nas zamknięta dusza ${ }^{62}$.

Ksiądz Młynarczyk oddziaływał na życie duchowe i sposób myślenia uczennic $^{63}$, wyposażając je w chrześcijański kodeks postępowania ${ }^{64}$. Uważał, że: „Życie religijne dzieci i młodzieży jest koniecznym uzupełnieniem czysto ludzkiego wychowania" ${ }^{65}$ i dlatego należy dbać o właściwy wybór form i metod pracy, treści nauczania, lekturę, które kształtują charakter i postawę młodego człowieka. Imponował swoim postępowaniem pełnym prostoty, skromności i pogody ducha. Był człowiekiem wielkich cnót i wiary, wzorem dla młodzieży. Halina Irena Szumił napisała o księdzu następujące słowa:

Całą duszą był oddany młodzieży, dla której dobra gotowy był poświęcić wszystko. Miał w sobie dużo taktu pedagogicznego [...] rozumiał dobrze mło-

${ }^{60}$ AGSł, D.II-31, Prywatne Żeńskie Seminarium Nauczycielskie (różne materiały) 1926-1932. Charakterystyczne listy byłych wychowanek seminarium do s. Wandy Józefy Sieradzkiej. List do s. W. J. Sieradzkiej z dnia 17 marca 1936 r. od absolwentki Marylki z Nowej Wsi, k. nlb.

${ }^{61}$ Szarotka, „Msza św. w naszym kościele”, Brzask 10 (1926): 7.

62 Olka (kurs II), „Wspomnienie z rekolekcji”, Brzask 10 (1926): 4-5.

${ }^{63}$ Langerówna, „Sodalicja”, 14.

${ }^{64}$ Bolesława Jarząbkówna, „Historia szkół w Mariówce. Referat wygłoszony przez B. Jarząbkównę, Przełożoną Średniej Szkoły Zawodowej w Płocku z okazji poświęcenia gmachu Gimnazjum i Liceum w Mariówce Opoczyńskiej w dniu 30 kwietnia 1939 r.”, Brzask 49 (1939): 10.

${ }^{65}$ Nauczyciel życia. Ks. Julian Młynarczyk 1882-1950, oprac. Halina I. Szumił (Sandomierz: Wydawnictwo Diecezjalne, 1996), 41. 
dzież, podchodził do niej z wiarą, pomagał jej w wyszukiwaniu i rozwijaniu tego, co jest w duszy ludzkiej szlachetne i dobre. Odznaczał się przy tym wielką skromnością i pokorą ${ }^{66}$.

Powyższe cechy pomagały mu w ofiarnej pracy duszpasterskiej i oświatowo-wychowawczej. Potrafił rozpoznawać problemy i docierać do uwarunkowań różnych postaw młodzieży. Posiadając naturę otwartą, komunikatywną, zdolność szybkiego nawiązywania kontaktów, zyskiwał zaufanie i autorytet wśród uczennic. Nauczał prawd wiary w sposób prosty, ze szczerością i przekonaniem. Poglądy, które głosił, popierał własnym przykładem. Uczennice obdarzały go dużym zaufaniem, z ufnością zwierzały mu się z różnych problemów, a on wspierał je w trudnych chwilach, krzepił na duchu ${ }^{67}$. Troszczył się o swoje wychowanki, dlatego starał się obdarzyć je najpiękniejszymi wartościami i poglądami, które pozwoliłyby im przezwyciężać w przyszłości życiowe trudności i wytrwale dążyć do wyznaczonych celów. Czynił to zawsze ze spokojem, opanowaniem, cierpliwością i rozwagą. Jego sposób bycia, pełen wyrozumiałości i taktu pedagogicznego, wzbudzał powszechny szacunek. Uczennice wielokrotnie wypowiadały opinię, iż ksiądz kanonik jako pedagog będzie dla nich wzorem do naśladowania ${ }^{68}$. W dowód wdzięczności nazywały księdza Czcigodnym Szermierzem, Drogim Ojcem i Nauczycielem ${ }^{69}$.

Ksiądz Młynarczyk czuwał nad sprawnym funkcjonowaniem szkół, pełnił funkcje prefekta i dyrektora, nadzorował wszystkie sprawy organizacyjne i dydaktyczno-wychowawcze, dlatego nazywany był często przez uczennice „duszą szkoły”. Dbał o ich wszechstronny rozwój. Posiadał także dar wpływania na dalsze zachowania uczennic, które przejmowały od niego wzory postępowania. Wypracował wysoki poziom nauczania, oparty na nowoczesnych formach i metodach pracy.

Ksiądz Młynarczyk był postacią o niezwykłej osobowości. Jego postawa, przekonania, zasady życiowe wyrażane były w sposób prosty i szczery. Słowem i czynem hołdował zasadom opartym na chrześcijańskim dekalogu oraz ogólnoludzkich uniwersalnych normach. Swoją mądrość i doświadczenie przekazywał młodemu pokoleniu. Imponował swoim postępowaniem pełnym prostoty, skromności i pogody ducha. Był człowiekiem wielkich cnót

\footnotetext{
${ }^{66}$ Tamże, 11.

${ }^{67}$ Grupa Literacka, „Ksiądz kanonik jako pedagog”, Brzask 9 (1929): 15-16.

68 Tamże, 16.

${ }^{69}$ Grupa Literacka, „Do księdza kanonika”, Brzask 9 (1929): 11-12.
} 
i głębokiej wiary, o niezwykłej osobowości, nieskazitelnym autorytecie moralnym i wzorem dla młodzieży. Żył Ewangelią, z niej czerpał siłę do swej działalności.

Po drugiej wojnie światowej w szkołach w Mariówce funkcję prefektów pełnili kolejno: ks. Symforian Paszkiewicz (1949-1950), ks. Józef Giżycki w 1950 roku, ks. Stanisław Flont (1951-1952), ks. Feliks Turbiarz (1952-1954), ks. Stanisław Chrzanowski w 1954 roku $^{70}$. Pracowali oni krótko i w trudnym okresie, kiedy nasilała się polityka inwigilacji młodzieży i wzmożenia ideologizacji szkolnictwa. W dokumentach szkolnych nie zachowały się informacje o działalności dydaktyczno-wychowawczej wymienionych prefektów szkolnych i dlatego nie można ocenić efektów ich pracy. Można natomiast przypuszczać, że była to praca niełatwa, gdyż w 1945 roku władze państwowe wypowiedziały konkordat ze Stolicą Apostolską z 1925 $\mathrm{roku}^{71}$. Z tego powodu zarówno pozycja Kościoła katolickiego w Polsce, jak i status prefektów oraz ich działalność były znacznie ograniczone.

\section{Zakończenie}

Wypracowany system działań wychowawczych w szkołach prowadzonych przez Zgromadzenie Sióstr Służek NMP Niepokalanej w Mariówce w latach 1903-1954 był rozbudowany, zindywidualizowany, ukierunkowany na wszechstronny i jak najpełniejszy rozwój uczennic. W korespondencji do s. Wandy Józefy Sieradzkiej, ks. Juliana Młynarczyka i innych nauczycieli uczennice wielokrotnie dawały wyraz swej wdzięczności za wkład pracy w ich rozwój, wyrażały podziękowania za otrzymane wychowanie katolickie, które umożliwiło im szersze, świadome spojrzenie na otaczającą rzeczywistość, odnalezienie się w życiu dorosłym, postępowanie uczciwe, honorowe, zgodne z nauką Ewangelii ${ }^{72}$. Absolwentki szkół w Mariówce swoją postawą dawały wzór moralności chrześcijańskiej. Efekty te osiąnnięte zostały dzięki wypracowanemu systemowi wychowawczemu, pedagogii, polegającej na harmonijnej współpracy oraz atmosferze sprzyjającej wszechstronnemu rozwojowi uczennic.

70 AGSł, D.II-19, Prywatne Koedukacyjne Gimnazjum Ogólnokształcące 1945-1957, Sprawozdanie statystyczne za rok szkolny 1953/1954, k. nlb.

${ }^{71}$ Hejnicka-Bezwińska, Praktyka, 211-215.

${ }^{72}$ AGSł, F.II, Korespondencja uczennic z ks. dyrektorem Julianem Młynarczykiem, Mariówka [b.r.], List Haliny Chrząstowskiej z 15 lipca 1939 r., k. nlb. 
Catholic Education at Schools

of Sisters Servants of Mary Immaculate

in Mariówka in the Years 1903-1954

(Summary)

The article presents the functioning of the schools run by Sisters Servants of Mary Immaculate in Mariówka at the background of the education development in Poland in the years 1903-1954. What is considered is the situation of the Catholic Church that approached then the matters of youth education with utmost care. At that time there were many religious congregations developing their own pedagogies and educational methods. In 1903 Sisters Servants of Mary Immaculate began an original educational program and since then they have worked out their own system of dealing with the youth which has guaranteed a Catholic education to pupils.

Keywords: catholic education; education system; Sisters Servants of Mary Immaculate; Mariówka.

\section{Wychowanie katolickie w szkołach Zgromadzenia \\ Sióstr Służek Najświętszej Maryi Panny Niepokalanej \\ w Mariówce w latach 1903-1954 (Streszczenie)}

Artykuł ukazuje działalność wychowawczą w szkołach prowadzonych przez Zgromadzenie Sióstr Służek NMP Niepokalanej w Mariówce w latach 1903-1954. Przedmiotem rozważań uczyniono sytuację Kościoła katolickiego, który ze szczególną troską podchodził do spraw wychowania katolickiego młodzieży. Działalność wychowawczą prowadziło także wiele zgromadzeń zakonnych, które wypracowały własne pedagogie. Od 1903 roku działalność dydaktyczno-wychowawczą podjęło Zgromadzenie Sióstr Służek NMP Niepokalanej w Mariówce i wypracowało własny system oddziaływań, zapewniając młodzieży wychowanie katolickie.

Słowa kluczowe: wychowanie katolickie; system wychowawczy; pedagogie zakonne; Zgromadzenie Sióstr Służek NMP Niepokalanej; Mariówka. 


\section{Bibliografia}

\section{Źródla}

Archiwum Główne Zgromadzenia Sióstr Służek NMP Niepokalanej w Mariówce: AGSł, A.II., Konstytucje Zgromadzenia 1919-1988.

AGSł, D.I-1, Towarzystwo „Samopomoc” 1922-1933 (przychodzące).

AGSł, D.I-1, Towarzystwo „Samopomoc” 1934-1947 (odchodzące).

AGSł, D.II-1, Niespodzianka 1920-1923.

AGSł, D.II-6, Kronika Koła Samokształcenia „Jedność” [1921-1936] w Mariówce [b.r.].

AGSł, D.II-7, Kronika Sodalicji Mariańskiej w Mariówce [b.r.].

AGSt, D.II-12, Brzask z lat 1926-1939.

AGS1, D.II-19, Prywatne Koedukacyjne Gimnazjum Ogólnokształcące 1945-1957.

AGSł, D.II-31, Organizacje, koła zainteresowań w szkołach w Mariówce [b.r.], Notatki.

AGSł, D.II-31, Prywatne Żeńskie Seminarium Nauczycielskie 1926-1932.

AGSł, F.II, Korespondencja uczennic z ks. dyrektorem Julianem Młynarczykiem, Mariówka [b.r.].

Konkordat pomiędzy Stolicą Apostolską a Rzeczypospolitą Polską, podpisany w Rzymie dnia 10 lutego 1925 r., Dz.U. 1925, nr 47, poz. 324.

Konstytucja Rzeczypospolitej Polskiej z dnia 17 marca 1921 r. Dz.U. 1921, nr 44, poz. 267 , art. 120.

Obwieszczenie Ministra WRiOP z dnia 9 listopada 1932 r. w sprawie ogłoszenia jednolitego tekstu ustawy z dnia 1 lipca 1926 r. o stosunkach służbowych nauczycieli. Dz.U. 1932, nr 104, poz. 873.

Okólnik MWRiOP z dnia 5 stycznia 1927 r. w sprawie nauki religii w publicznych szkołach powszechnych. Dz.Urz. MWRiOP 1927, nr 2, poz. 32.

Pius PP X. Codex Iuris Canonici, Pontificis Maximi iussu digestus, Benedicti XV auctoritate promulgatus, Roma 1917.

Pius PP XI. „Orbem catholicum cum primum colloquimur”. Acta Apostolicae Sedis (1923): 327-329.

Pius PP XI. Encyklika „Divini Illius Magistri” [O chrześcijańskim wychowaniu mtodzieży]. Tłum. J. Korzonkiewicz. Poznań: Kancelaria Prymasa Polski, 1932.

Pius PP XI. „Provido sane consilio”. Acta Apostolicae Sedis (1935): 145-154.

Rozporządzenie Ministra MWRiOP z dnia 9 grudnia 1926 r. o nauczaniu religii katolickiej. Dz.U. 1927, nr 1, poz. 9. 
Ustawa z dnia 4 czerwca 1920 r. o tymczasowym ustroju władz szkolnych. Dz.U. 1920, nr 50, poz. 304. Dz.Urz. MWRiOP 1920, nr 18, poz. 11.

Ustawy Komisji Edukacji Narodowej dla stanu akademickiego i na szkoły w krajach Rzeczypospolitej przepisane w Warszawie, rok 1783. Lwów: Księgarnia Naukowa, 1930.

\section{Opracowania}

Adamski, Stanisław. Szkoła wedle nauki Kościoła i uchwał Synodu. Cz. 1. Poznań: Nakładem Przewodnika Katolickiego: Drukarnia i Księgarnia św. Wojciecha, 1939.

Chiberska, Janina. „Grupa Literacka”. Brzask 18 (1934): 18.

Chmielewski, Witold. „Rola rodziny w wychowaniu religijnym dzieci i młodzieży w okresie powojennym". Przeglad Historyczno-Oświatowy 1-2 (2010): 83-90.

Czechówna, Kazimiera, Zofia Jakubowska. „Grupa Literacka”. Brzask 34 (1936): 8-9.

Doroszewski, Jerzy. „Życie organizacyjne młodzieży w seminariach nauczycielskich w latach 1918-1937". Przeglad Historyczno-Oświatowy 2 (2002): 71-83.

Grupa Literacka. „Do księdza kanonika”. Brzask 9 (1929): 11-12.

Grupa Literacka. „Ksiądz kanonik jako pedagog”. Brzask 9 (1929): 15-16.

Hejnicka-Bezwińska, Teresa. Praktyka edukacyjna w warunkach zmiany kulturowej.

Warszawa: Wydawnictwo Naukowe PWN, 2015.

Jarząbkówna, Bolesława. „Historia szkół w Mariówce. Referat wygłoszony przez

B. Jarząbkównę, Przełożoną Średniej Szkoły Zawodowej w Płocku z okazji poświęcenia gmachu Gimnazjum i Liceum w Mariówce Opoczyńskiej w dniu 30 kwietnia 1939 r.”. Brzask 49 (1939): 10.

Jusiak, Roman. „Pedagogia franciszkańska”. W: Pedagogie katolickich zgromadzeń zakonnych. Historia i wspótczesność, t. 1, red. Janina Kostkiewicz, 21-34. Kraków: Oficyna Wydawnicza „Impuls”, 2012.

Kawińska, Irena. „Koło Samokształcenia Jedność”. Brzask 18 (1931): 11-12.

Kopaliński, Władysław. Słownik wyrazów obcych i zwrotów obcojęzycznych. Warszawa: Wiedza Powszechna, 1989.

Kostkiewicz, Janina. „Pedagogie katolickich zgromadzeń zakonnych - wprowadzenie w problematykę". W: Pedagogie katolickich zgromadzeń zakonnych. Historia $i$ wspótczesność, red. Janina Kostkiewicz, t. 1, 11-20. Kraków: Oficyna Wydawnicza „Impuls”, 2012.

Kunowski, Stefan. Podstawy współczesnej pedagogiki. Warszawa: Wydawnictwo Salezjańskie, 1993. 
Langerówna, Irena. „Sodalicja”. Brzask 34 (1931): 14-15.

Majcher, Edward. Działalność katechetyczna ośrodka warszawskiego w latach 1918 -1939 na tle ówczesnego ruchu katechetycznego. Warszawa: Wydawnictwo Archidiecezji Warszawskiej, 1996.

Materski, Edward. „Katecheta”. W: Encyklopedia katolicka, red. Andrzej Szostek, Bogusław Migut, Edward Gigilewicz, t. 8, 1014-1015. Lublin: Towarzystwo Naukowe KUL, 1989.

Mazurek, Maria. „Koźmiński Florentyn Wacław”. W: Hagiografia polska. Stownik bio-bibliograficzny, red. Romuald Gustaw, t. 1, 863-885. Poznań: Księgarnia św. Wojciecha, 1971.

Mazurek, Maria H. Powstanie i rozwój ukrytych Zgromadzeń bt. Honorata Koźmińskiego. Sandomierz: Wydawnictwo Diecezjalne, 2009.

Młynarczyk, Julian. Ksztatcenie serca na podstawach etyki Chrystusowej. Mariówka: Wydawnictwo Szkoły Rzemiosł, 1925.

Młynarczyk, Julian. Bóg miłościq. Mariówka: Wydawnictwo Szkoły Rzemiosł, 1929.

Młynarczyk, Julian. Nasz internat. Mariówka: Wydawnictwo Szkoły Rzemiosł, 1943.

Musielewicz, Krystyna. „Nowy gmach”. Brzask 42 (1937): 6.

Nauczyciel życia. Ks. Julian Młynarczyk 1882-1950, oprac. Halina I. Szumił. Sandomierz: Wydawnictwo Diecezjalne, 1996.

Olka (kurs II). „Wspomnienie z rekolekcji”. Brzask 10 (1926): 4-5.

Pedagogika. Leksykon PWN. red. Bogusław Milerski, Bogusław Śliwerski. Warszawa: Wydawnictwo PWN, 2000.

Polak, Ryszard. Religia rzymskokatolicka w szkołach II Rzeczypospolitej. Lublin: Wydawnictwo Polihymnia, 2007.

Redakcja. „Kronika”. Brzask 19 (1928): 20.

Redakcja. „Nasz hymn”. Niespodzianka marzec (1922): 6.

Rowid, Henryk. Podstawy i zasady wychowania, Warszawa: Wydawnictwo Oświatowe „Wspólna Sprawa”, 1957.

Szarotka. „Msza św. w naszym kościele”. Brzask 10 (1926): 7.

Szczepaniak, Jan. Troska Kościoła o nauczanie $i$ wychowanie religijne w Polsce w latach 1918-1927. Kraków: Wydawnictwo WAM, 1997.

Szylar, Anna. „Ideały wychowawcze w klasztornych szkołach żeńskich w okresie potrydenckim do początków XIX wieku". Paedagogia Christiana 2 (2012): 11-14.

Wałęga, Agnieszka. „Obraz edukacji religijnej w Galicji 2. połowy XIX wieku w opinii współpracowników lwowskiej Szkoły". Paedagogia Christiana 1 (2017): 171-198.

Wójcik, Maria. Zgromadzenie Sióstr Stużek NMP Niepokalanej, t. 1: Powstanie, rozwój i działalność w latach 1878-1918. Poznań: Pallottinum, 1978. 
Wójcik, Maria. Prywatne Gimnazjum i Liceum Ogólnokształcące im. Błogosławionej Jadwigi w Mariówce. Sandomierz: Wydawnictwo Diecezjalne, 1995.

Wójcik, Maria. „Działalność wydawnicza drukarni w Mariówce Opoczyńskiej Zgromadzenia Sióstr Służek NMP Niepokalanej w latach 1921-1930”. W: W kręgu dziejów Kościoła i rodziny franciszkańskiej, red. Roland Prejs, 343-352. Warszawa: Bracia Mniejsi Kapucyni, 1999.

Wójcik, Maria. „Prywatne Seminarium Nauczycielskie Żeńskie w Mariówce Opoczyńskiej w latach 1921-1936”. Studia Sandomierskie 6 (1990): 540.

Wójcik, Maria. Stulecie działalności Zgromadzenia Sióstr Stużek NMP Niepokalanej w Mariówce (1903-2003). Mariówka: Wydawnictwo Diecezjalne, 2004.

Wójcik, Maria. Zgromadzenie Sióstr Stużek NMP Niepokalanej, t. 2: Rozwój i działalność w latach 1919-1978. Sandomierz: Wydawnictwo Diecezjalne, 2012.

Zakrzewska, Aldona. „Edukacja religijna dzieci i młodzieży szkolnej okresu międzywojennego źródłem humanizacji życia społecznego". Paedagogia Christiana 2/30 (2012): 47-53.

Zarembianka, Natalia. „W służbie Marji. Przysięga”. Brzask 34 (1936): 4-5. 